\title{
Evaluation of Freezing Tolerance of Hexaploid Triticale Genotypes under Controlled Conditions
}

\author{
Ahmad NEZAMI'), Mohammad Reza SOLEIMANI'), Masoud ZIAEE ${ }^{2)}$ \\ Masoud GHODSI' ${ }^{3}$, Mohammad BANNAYAN AVAL ${ }^{1)}$ \\ ${ }^{1)}$ Ferdowsi University of Mashhad, Faculty of Agriculture, Mashhad, Iran; bannayan@um.ac.ir (corresponding author) \\ ${ }^{2)}$ University of Sistan and Baluchestan, Faculty of Agriculture and Natural Resource of Saravan, Department of Medicinal Plant, Saravan, Iran \\ ${ }^{3)}$ Khorasan Agriculture Center of Cereals Division, Mashhad, Iran
}

\begin{abstract}
In order to evaluate freezing tolerance of different triticale (X Triticosecale Wittmack) genotypes, an experiment was carried out under controlled conditions in 2007 and 2008 at college of agriculture, Ferdowsi University of Mashhad. In this study seeven triticale genotypes ('Juanilo-92', 'ET-82-15', 'ET-82-8', 'ET-83-20', 'ET-83-19', 'ET-83-18' and 'ET-79-17'), across six temperatures $\left(0^{\circ} \mathrm{C},-4^{\circ} \mathrm{C}\right.$, $-8^{\circ} \mathrm{C},-12^{\circ} \mathrm{C},-16^{\circ} \mathrm{C}$ and $-20^{\circ} \mathrm{C}$ ) were evaluated within a factorial-completely randomized design with three replications. Plants were kept until 2 leaf stage in chamber with temperature of $20 / 15^{\circ} \mathrm{C}$ (day/night) and 12.5 h photoperiod. At the end of this stage, plants were under acclimation for three weeks. After exposing to acclimation freezing the cell membrane integrity was measured through electrolyte leakage (EL) and the lethal temperature (LT50) of samples was measured. After the exposure to freezing temperatures the samples were transferred to the greenhouse. Survival percentage, plant height, leaf area and number, chlorophyll content, and plant dry weight were determined after 3 weeks. Results showed that the effect of different freezing temperature and genotypes were significant on all plant characteristics. As temperature decreased, \%EL of all genotypes was increased. Minimum and Maximum EL \% in leaf and crown were observed at $0^{\circ} \mathrm{C}(21 \%)$ and $-20^{\circ} \mathrm{C}(88.5 \%)$. 'ET-79-17' and 'Juanilo-92' genotypes showed the highest EL\% (55.5\% and 44.8\%) and 'ET83-20' the lowest EL\% (47.3\% and 41.2\%) in leaf and crown. Dry weight and leaf area decreased by $48 \%$ and $42 \%$ respectively compared to non frozen control plants. 'ET-79-17' and 'ET-82-15' genotypes showed the highest dry weight (83.8 mg) and highest leaf area (14.3 $\left.\mathrm{cm}^{2}\right)$ respectively and 'ET-83-20' cultivar showed the lowest dry weight and leaf area $\left(58.2 \mathrm{mg}\right.$ and $\left.8.7 \mathrm{~cm}^{2}\right)$.
\end{abstract}

Keywords: plant cold acclimation, electrolyte leakage, plant freezing recovery, LT50

\section{Introduction}

Triticale (X Triticosecale Wittmack) has been deliberately produced by crossing wheat (Triticum aestivum L.) and rye (Secale cereale L.) plants. Triticale contains the privileges of both parents, high quality for making various food products along with robustness of adaptability to hard environment conditions and disease resistance (Ammar, 2004). The grains of triticale contain more protein, lysine and minerals compared to cereals such as wheat, rice and corn with equal amount of vitamins compared to wheat (Barnett et al., 1971). Triticale is grown for grain and also forages for livestock in the temperate winter zone (Brown and Almodares, 1976). According to FAO statistics (FAO, 2008) 3.5 million ha triticale are grown in the world with 14 million tones production of more than 200 cultivars in almost 35 countries.

Average annual precipitation in Iran is about $250 \mathrm{~mm}$, only about one third of the world rainfall. On the other hand limited precipitation is mainly confined to cold and winter month (Ghamarnia and Gowing, 2005). Therefore farmers in Iran desire more winter cropping for from the benefit of winter rainfall, which increase with 15-25 percent the yield and avoid drought stress (Dashti et al., 2001).

This crop is relative tolerant to the environmental stresses (Brown and Almodares, 1976). One of the most important environment stresses is the frost which limits the growth and the yield of winter cereals including triticale. Freezing causes serious damages to plants by injuring the plant cells and tissues. Hence, the cold tolerant cultivars play an important role in the success of the production of the winter cereals (Moshiri et al., 2006).

Many studies have been conducted to find an effective and rapid method to evaluate the plants tolerance to freezing temperatures. One of these methods is measuring the cytoplasm membrane electrolyte leakage or the conductivity of acclimated organs which can be damaged due to the freezing stress (Mirzai-Asl et al., 2002). Since the cytoplasm membrane is the first place that can be damaged, it is possible to determine the amount of injury through the electrolyte leakage of damaged tissues. It is expected that susceptible cells can be damaged more than tolerant ones and show higher electrolyte leakage (Beyrami Zade, 2006). 
Electrolyte leakage (EL) method is easy, fast, and reliable and demand less expenses compared to the other methods, thus it is a suitable method to determine the plant tolerance to coldness (Lyons et al., 1990). Hommo (1994), working on 13, 10, 3 and 6 cultivars of wheat (Triticum aestivum L.), rye (Secale cereale L.), triticale (X Triticosecale Wittmack) and winter barley (Hordeum vulgare L.) respectively, found a significant correlation between the EL\% of plant leaves and crop survival from freezing.

Similarly, Pulli (1994) studied 9, 10 and 12 cultivars of wheat (Triticum aestivum L.), rye (Secale cereale L.) red clover (Trifolium pretense) and found a significant correlation between crop survival and EL\% of leaves though this relation was not significant for rye crops.

Another evaluation method for freezing tolerance is to measure the growth characteristics and the plant regrowth after the recovery period which is followed by the freezing test in controlled conditions. Fowler and Carlers (1979), on wheat (Triticum aestivum L.) study, found a significant correlation between the plants shoot dry weight during the recovery period and Lethal temperature 50 (LT50) in field condition. In addition, a positive significant correlation was found between the chlorophyll amount (SPAD), plant height, leaf area and dry weight with LT50 under the recovery period (Azizi et al., 2007). Nezami et al., (2007) observed that at $-12^{\circ} \mathrm{C}$ the plant dry weight of tolerant genotypes was $40 \%-45 \%$ less than the control plant $\left(0^{\circ} \mathrm{C}\right)$ dry weight. However the dry weight of sensitive genotypes was only $10 \%$ the control plant. The objective of this study was to evaluate various triticale genotypes exposed to the freezing stress under controlled conditions.

\section{Materials and methods}

\section{Plant establishment}

Seven triticale genotypes ('Juanilo-92', 'ET-82-15', 'ET-82-8', 'ET-83-20', 'ET-83-19', 'ET-83-18' and 'ET79-17') across six different temperatures $\left(0^{\circ} \mathrm{C},-4^{\circ} \mathrm{C},-8^{\circ} \mathrm{C}\right.$, $-12^{\circ} \mathrm{C},-16^{\circ} \mathrm{C}$ and $-20^{\circ} \mathrm{C}$ ) were employed in this research. The seeds were put to germinate in the Petri-dishes using the moist filter papers. After 3 days, germinated seeds were sown in plastic pots $(9.5 \mathrm{~cm}$ diameter $)$ that were primarily filled with an equivalent ratio of sand, compost and farm soil with 2-3 cm depth and 10 seeds of each genotype were planted. After that, pots were immediately transferred to the growth chambers. The growth chamber temperature and photoperiod for seedlings were set as $20 / 15^{\circ} \mathrm{C}$ (day/ night) and $12.5 \mathrm{~h}$ light duration.

\section{Acclimation conditions}

At the plants' second leaf stage (when $50 \%$ of plants second true leaf appeared) freezing acclimation conditions were set for three weeks as described below.

The first week, $10 / 8^{\circ} \mathrm{C}$ (day/night) and $11.5 \mathrm{~h}$ light; the second week, $7 / 5^{\circ} \mathrm{C}$ (day/night) and $10.5 \mathrm{~h}$ light and the third week $5 / 2^{\circ} \mathrm{C}$ (day/night) and $10.5 \mathrm{~h}$ light. Af- ter three weeks, the pots were transferred to the Thermo Gradient Freezer. The initial temperature of the freezing chamber was $5^{\circ} \mathrm{C}$, however the temperature was decreased linearly at the rate of $2^{\circ} \mathrm{C}$ per hour. When the temperature cooled down to $-3^{\circ} \mathrm{C}$, the seedlings were sprayed with the Ice Nucleation Active Bacteria (INAB) to help the formation of the ice nucleic in the seedlings tissues (Lindow and et al., 1982). Followed by the freezing treatment, the samples were transferred to the growth chamber at $5 \pm 1^{\circ} \mathrm{C}$ for $24 \mathrm{~h}$ to decrease the rate of thawing.

\section{Electrolyte leakage evaluation}

To employ the EL method, three plants from each pot were removed and their leaves and crowns were separated and placed in the vials containing the double distilled water. The samples were then placed on a shaker for $6 \mathrm{~h}$ before measuring the primary EL. The EL measurement was made using an EC meter (Jenway-Model). To evaluate total electrolyte leakage of the dead cells, the samples were frozen at $-70^{\circ} \mathrm{C}$ for $24 \mathrm{~h}$ in a cold chamber. Subsequently the samples were transferred to the laboratory and exposed to the natural temperature to defreeze. The second EL measurement was then made by placing the samples on the shaker for $6 \mathrm{~h}$. The EL \% was calculated as:

$\mathrm{EL}=\left(\mathrm{EL}_{1} / \mathrm{EL}_{2}\right) \times 100(1)$

$\mathrm{EL}_{1}=$ Primary reading electrolyte leakage after treatment $-70^{\circ} \mathrm{C}$

$\mathrm{EL}_{2}=$ Total reading electrolyte leakage after freezing to

\section{Recovery evaluation}

The pots containing the other remained seven plants were transferred to the greenhouse for 21 days and their re-growth was evaluated. The percentage of the survived seedlings was determined by counting the alive plants from each pot as:

$\mathrm{PSI}=(\mathrm{A} / \mathrm{B}) \times 100(2)$

PSI $=$ Survival Percentage Index

$A=$ Number of alive plants in recovery period after 3 weeks

$B=$ Number of plants before freezing treatment

After the recovery period, five plants from each pot were harvested to determine the plants height (from the soil surface to the last node), the number of leaves, leaf area, leaf chlorophyll content (using three young expanded leaves) and plants dry weight. Plant height was also measured again at heading stage.

\section{Statistical analysis}

The experiment was arranged in a factorial completely randomized design with three replications. LT50 was calculated from a graph of EL\% verses temperature and data were analyzed by using the statistical software MSTAT-C followed by the calculation of LSD test at $5 \%$ probability level. The percentage data were transformed to arcsine prior to analysis. 
116

\section{Results and discussion}

\section{Electrolyte leakage method}

\section{Electrolyte leakage percentage}

Significant effect of different freezing temperatures over EL\% of both the leaves and crowns were found (P $\leq 0.01$ ) (Tab. 1). As temperature decreased, the EL\% increased. The leaves EL\% were 1.3, 1.9, 2.6, 3.5 and 4.2 times higher at $-4^{\circ} \mathrm{C},-8^{\circ} \mathrm{C},-12^{\circ} \mathrm{C},-16^{\circ} \mathrm{C}$ and $-20^{\circ} \mathrm{C}$ compared to the control condition (Tab. 2). For leaves the minimum and the maximum EL\% were obtained at $0^{\circ} \mathrm{C}$ $(21 \%)$ and $-20^{\circ} \mathrm{C}(88.5 \%)$, respectively (Tab. 2). Similar results were found for the EL\% of the crowns. By decreasing the temperature EL\% of the crowns increased. The EL\% of crowns was 1.1, 1.3, 1.6, 1.9 and 2.2 times higher at $-4^{\circ} \mathrm{C},-8^{\circ} \mathrm{C},-12^{\circ} \mathrm{C},-16^{\circ} \mathrm{C}$ and $-20^{\circ} \mathrm{C}$ compared to the control. The minimum and the maximum EL\% level were observed at $0^{\circ} \mathrm{C}(29.2 \%)$ and $-20^{\circ} \mathrm{C}(64.6 \%)$, respectively (Tab. 2). When the leaves of rose clover (Trifolium hirtum All.) genotypes were exposed to the different freezing temperatures, there was a significant difference between the 'ET-83-20' about $47.3 \%$. The same results were found by Eugenia et al., (2003). They found a significant difference between the EL\% of leaves within the rose clover genotypes. Since, the EL\% ranged from $51.1 \%$ to $61.5 \%$.

\section{Lethal temperature (LT50)}

The temperature in which the electrolyte leakage is $50 \%$ is known as lethal LT50 (Gusta et al., 1982). In this experiment, there was a significant difference $(P \leq 0.01)$ between triticale genotypes for the leaves and crowns LT50 (Tab. 4). Since, 'ET-83-18' and 'ET-83-19' having the leaf LT50 of $-13.6^{\circ} \mathrm{C}$ and $-11^{\circ} \mathrm{C}$ were noted as the most tolerant and the most sensitive genotypes, respectively (Tab. 3). However, when comparing the crowns LT50 within the genotypes, Juanilo- $92\left(-13.9^{\circ} \mathrm{C}\right)$ and 'ET-82-8' $\left(-9.2^{\circ} \mathrm{C}\right)$ were the most tolerant and the most sensitive genotypes, respectively (Tab. 3). Anderson et al., (1993) studying on Bermudagrass [Cynodon dactylon (L.) Pers. $\times$ C. transvaalensis Burt-Davy] reported that there is a significant difference between the genotypes for LT50. The LT50 ranged from $-7^{\circ} \mathrm{C}$ to $-11^{\circ} \mathrm{C}$ between the genotypes. Similarly, Nezami et al. (2007) found a clear difference on

Tab. 1. Source of variation (SV), degree of freedom (df) and mean square (Ms) of measured plant parameters exposed to different freezing temperature and recovery in greenhouse of different triticale genotypes

\begin{tabular}{|c|c|c|c|c|c|c|c|c|c|}
\hline SV & $\mathrm{df}$ & & & & Ms & & & & \\
\hline & & El leaf (\%) & El crown $(\%)$ & Height $(\mathrm{cm})$ & $\mathrm{LN}$ & $\mathrm{LA}(\mathrm{cm})$ & SPAD & $\mathrm{DW}(\mathrm{mg})$ & $\mathrm{HH}(\mathrm{cm})$ \\
\hline Temperature & 5 & $14625.11^{*}$ & $3926.39^{*}$ & $437.79^{*}$ & $107.60 "$ & $2039.48^{*}$ & $7651.90^{\circ}$ & 78240.36 & $8774.25^{\prime \prime}$ \\
\hline Genotype & 6 & $157 / 11^{\circ}$ & $43.52^{\mathrm{ns}}$ & $14.58^{* \prime}$ & $1.43^{*}$ & $55.66^{\circ}$ & $21.22^{*}$ & $1528.85^{\circ \prime}$ & $2314.84^{*}$ \\
\hline $\mathrm{T} \times \mathrm{G}$ & 30 & $41 / 44^{\mathrm{ns}}$ & $43.36^{\mathrm{ns}}$ & $1.67^{\circ}$ & $0.20^{\prime \prime}$ & $9.42^{*}$ & $3.86^{\mathrm{ns}}$ & $239.13^{\text {ns }}$ & $268.82^{*}$ \\
\hline Error & 84 & 69.23 & 53.91 & 0.19 & 0.05 & 5.17 & 2.85 & 271.43 & 22.14 \\
\hline
\end{tabular}

(EL\%) Electrolyte leakage percentage; (LN) Leaf number; (LA) Leaf area; (SPAD) Chlorophyll content; (DW) Total dry weight; (HH) Height at heading stage

the EL\% at different freezing temperatures (Eugenia et al., 2003). Thus decreasing the temperature down to $-18^{\circ} \mathrm{C}$ caused an increase in the EL\% of leaves up to 5.7 times more than at $-6^{\circ} \mathrm{C}$. Similar result was reported by Murray et al. (1994). They found a significant correlation between the EL\% leaves of winter oat (Avena sativa L. cv. 'Kanota') at different freezing temperature, since the EL\% at $-28^{\circ} \mathrm{C}$ was $80 \%$ higher than control condition $\left(0^{\circ} \mathrm{C}\right)$.

Different genotypes showed significant different leaves EL\% $(P \leq 0.05)$ however it was not significant for the EL\% of the crowns (Tab. 1). The 'ET-79-17' had the highest leaf EL\% (55.5\%) and the lowest EL\% was obtained for

Tab. 2. Source of variation (SV), degree of freedom (df) and mean square (Ms) of lethal temperature 50 (LT50) in leaf and crown of different triticale genotypes

\begin{tabular}{cccc}
\hline SV & df & \multicolumn{2}{c}{ MS } \\
\hline & & LT50 leaf & LT50 crown \\
Genotype & 6 & $1.712^{* *}$ & $31.829^{* *}$ \\
Error & 14 & 0.448 & 1.815 \\
\hline
\end{tabular}

the leaf LT50 among different genotypes of colza (Brassica napus L.) under the freezing condition.

\section{Plant re-growth}

\section{Survival percentage}

There were no differences between the genotypes for percentage of survived seedlings. The survived seedlings percentage for all genotypes was $100 \%$ until the temperature decreased to $-12^{\circ} \mathrm{C}$. All seedlings were lost at $-16^{\circ} \mathrm{C}$ and $-20^{\circ} \mathrm{C}$. Therefore we couldn't measure LT50 by survival percentage.

\section{Plant height}

As temperature decreased, the plants height also decreased (Tab. 2). The effect of different freezing temperatures on plant height was significant $(\mathrm{P} \leq 0.01)$ ( Tab. 1). In living plants, the maximum and the minimum height were obtained at $0^{\circ} \mathrm{C}(9.8 \mathrm{~cm})$ and $-12^{\circ} \mathrm{C}(7.7 \mathrm{~cm})$, respectively. The same result for wheat was observed by Azizi et al. (2007). They reported that the plant height decreased as temperature decreased and shoot height was 16\% lower 
Tab. 3. Freezing temperature effects on various measured plant parameters

\begin{tabular}{ccccccccccc}
\hline Treatment & El leaf $(\%)$ & El crown $(\%)$ & SPI & Height $(\mathrm{cm})$ & LN & LA $\left(\mathrm{cm}^{2}\right)$ & SPAD & DW $(\mathrm{mg})$ & HH $(\mathrm{cm})$ \\
\hline 0 & & \multicolumn{7}{c}{ Freezing temperature $\left({ }^{\circ} \mathrm{C}\right)$} & & \\
\hline-4 & 21.0 & 29.2 & 100.0 & 9.8 & 4.8 & 22.9 & 39.8 & 145.0 & 46.9 \\
-8 & 40.1 & 32.7 & 100.0 & 9.1 & 4.5 & 19.7 & 38.0 & 119.5 & 40.4 \\
-12 & 53.9 & 45.3 & 100.0 & 7.7 & 3.7 & 13.2 & 33.6 & 75.1 & 28.5 \\
-16 & 73.9 & 55.6 & 0.0 & 0.0 & 0.0 & 0.0 & 0.0 & 0.0 & 0.0 \\
-20 & 88.5 & 64.6 & 0.0 & 0.0 & 0.0 & 0.0 & 0.0 & 0.0 & 0.0 \\
LSD (0.05) & 5.1 & 4.5 & -5 & 0.3 & 0.1 & 1.4 & 1.0 & 10.1 & 2.9 \\
\hline
\end{tabular}

\$Data analyzed is not possible; (EL\%) Electrolyte leakage percentage; (LN) Leaf number; (LA) Leaf area; (SPAD) Chlorophyll content; (DW) Total dry weight; $(\mathrm{HH})$ Height at heading stage

at $-12^{\circ} \mathrm{C}$ compared to the control condition. Similarly, the height of chickpea plants (Cicer arietinum $\mathrm{L}$.) at $-12^{\circ} \mathrm{C}$ was $45 \%$ lower than those under the control condition (Neza$\mathrm{mi}, 2002)$. The role of water in the frost hardiness of plant cells has been recognized primarily in terms of tissue water content and frost survival, so there are similar indications injury of freezing stress and drought stress (Cloutier and Siminovitch, 1982). Probably freezing stress decreased the plant height by reducing the cell division and size cells. These differences in plants height were also significant ( $\mathrm{P}$ $\leq 0.01$ ) between the plant genotypes (Tab. 1). The tallest plants were obtained from 'ET-82-8' whereas the 'ET83-20' produced the shortest plants (Tab. 3). Previously, Mirzai-Asl et al. (2002) by working on wheat observed a significant difference between the height of genotypes while the plant height ranged between $6.8 \mathrm{~cm}$ to $19.3 \mathrm{~cm}$. In addition, the interaction between the temperature and the cultivar on plant height was also significant $(P \leq 0.01)$ (Tab. 1). 'ET-82-8' was the highest at $0^{\circ} \mathrm{C}(11.9 \mathrm{~cm})$ while 'ET-83-20' produced the shortest plants $(5.3 \mathrm{~cm})$ at $-12^{\circ} \mathrm{C}$ (Tab. 5). At $-12{ }^{\circ} \mathrm{C}$ the height of 'ET-79-17' and 'ET-8215 ' were $33 \%$ and $17 \%$ lower than control treatments, respectively.

\section{Number of leaves}

In several crop species severe wilting of the leaves occurs within the first few hours of exposure to freezing tem- perature. This quickly leads to the development of necrotic patches over the leaf surface and induces drying of the leaf edges (Ristic and Ashworth, 1997). The effect of different freezing temperatures on the number of leaves was significant $(P \leq 0.01)($ Tab. 1$)$. The maximum and the minimum levels were obtained at $0^{\circ} \mathrm{C}\left(4.8\right.$ leaves) and $-12^{\circ} \mathrm{C}(3.7$ leaves), respectively. The number of leaves at $-4^{\circ} \mathrm{C},-8^{\circ} \mathrm{C}$ and $-12^{\circ} \mathrm{C}$ was $6.2 \%, 10.4 \%$ and $22.9 \%$ lower in comparison with the control condition (Tab. 2). These differences were also significant even between the genotypes (Tab. 1). 'ET-82-8' showed the highest number of leaves (3.3) whereas the 'Juanilo- 92' produced the lowest number of leaves (2.5) at the end of the recovery period (Tab. 3). The interaction between the genotype and the temperature on the number of leaves was also significant $(P \leq 0.01)$. The maximum level was observed for the 'ET- $82-8$ ' at $0{ }^{\circ} \mathrm{C}$ (5.4 leaves) and the minimum level was obtained for the Juanilo-92 at $-12^{\circ} \mathrm{C}$ (3.3 leaves) (Tab. 6). Reducing the temperature from $0^{\circ} \mathrm{C}$ to $-12^{\circ} \mathrm{C}$ caused a $25 \%$ decrease of the number of leaves in ET-82-17, however, this reduction was $16 \%$ for the 'ET- $82-15$ '.

\section{Leaf area}

One of the first symptoms of drought and cold is the reduction of cell expansion and therefore leaf growth. Temperature showed a significant effect $(P \leq 0.01)$ on leaf area (Tab. 1). As the temperature decreased, the leaf area

Tab. 4. Plant parameters of different genotype exposed to freezing temperature

\begin{tabular}{cccccccccc}
\hline Genotype & EL leaf $(\%)$ & $\begin{array}{c}\text { LT50 } \\
\text { leaf }\end{array}$ & $\begin{array}{c}\text { LT50 } \\
\text { crown }\end{array}$ & $\begin{array}{c}\text { Height } \\
(\mathrm{cm})\end{array}$ & LN & LA $\left(\mathrm{cm}^{2}\right)$ & SPAD & DW $(\mathrm{mg})$ & $\mathrm{HH}(\mathrm{cm})$ \\
\hline & & & & & & & & & \\
'ET-83-19' & 52.3 & -11.0 & -13.5 & 5.6 & 3.1 & 11.6 & 23.1 & 75.1 & 29.9 \\
'ET-83-18' & 47.9 & -13.6 & -12.2 & 6.0 & 3.1 & 12.1 & 24.6 & 75.9 & 24.9 \\
\hline 'ET-82-8' & 51.0 & -12.5 & -9.2 & 7.1 & 3.3 & 13.1 & 23.0 & 70.6 & 31.2 \\
'ET-82-15' & 53.0 & -11.3 & -12.4 & 5.9 & 2.7 & 14.3 & 25.2 & 82.2 & 31.6 \\
\hline Juanilo-92 & 49.3 & -12.6 & -13.9 & 6.1 & 2.5 & 11.4 & 24.8 & 64.6 & 28.9 \\
'ET-79-17' & 55.5 & -12.0 & -10.9 & 6.1 & 2.7 & 12.9 & 24.5 & 83.8 & 30.1 \\
\hline 'ET-83-20' & 47.3 & -12.2 & -13.6 & 4.1 & 2.8 & 8.7 & 26.1 & 58.2 & 0.0 \\
\hline LSD(0.05) & 5.5 & 1.2 & 2.7 & 0.3 & 0.1 & 1.5 & 1.1 & 10.9 & 3.1 \\
\hline
\end{tabular}

(EL\%) Electrolyte leakage percentage; (LN) Leaf number; (LA) Leaf area; (SPAD) Chlorophyll content; (DW) Total dry weight; (HH) Height at heading stage 
118

Tab. 5. The interactive effects of temperature and genotypes on various measured plant parameters exposed to freezing temperature

\begin{tabular}{|c|c|c|c|c|c|c|c|c|c|c|c|}
\hline Genotype & Temperature & $\begin{array}{l}\text { Height } \\
(\mathrm{cm})\end{array}$ & $\mathrm{LN}$ & $\mathrm{LA}\left(\mathrm{cm}^{2}\right)$ & $\mathrm{HH}$ & Genotype & Temperature & $\begin{array}{l}\text { Height } \\
(\mathrm{cm})\end{array}$ & LN & $\mathrm{LA}\left(\mathrm{cm}^{2}\right)$ & $\mathrm{HH}$ \\
\hline \multirow[t]{6}{*}{ 'ET-83-19' } & 0 & 9.5 & 5.1 & 21.0 & 53. & 'ET-83-18' & 0 & 9.9 & 5.3 & 22.7 & 50.7 \\
\hline & -4 & 8.8 & 4.9 & 19.3 & 49.3 & & -4 & 9.2 & 5.0 & 20.7 & 40.6 \\
\hline & -8 & 7.9 & 4.7 & 16.0 & 41.3 & & -8 & 8.6 & 4.9 & 17.0 & 35.3 \\
\hline & -12 & 7.4 & 3.9 & 13.1 & 35.2 & & -12 & 8.0 & 3.7 & 12.0 & 22.4 \\
\hline & -16 & 0.0 & 0.0 & 0.0 & 0.0 & & -16 & 0.0 & 0.0 & 0.0 & 0.0 \\
\hline & -20 & 0.0 & 0.0 & 0.0 & 0.0 & & -20 & 0.0 & 0.0 & 0.0 & 0.0 \\
\hline \multirow[t]{6}{*}{ 'ET-82-8’ } & 0 & 11.9 & 5.4 & 24.7 & 52.8 & 'ET-82-15' & 0 & 9.7 & 4.4 & 26.7 & 64.0 \\
\hline & -4 & 11.3 & 5.2 & 20.0 & 49.8 & & -4 & 8.8 & 4.3 & 24.7 & 47.3 \\
\hline & -8 & 9.9 & 4.9 & 18.0 & 45.7 & & -8 & 8.6 & 3.9 & 18.0 & 42.2 \\
\hline & -12 & 9.4 & 4.0 & 15.7 & 38.7 & & -12 & 8.0 & 3.7 & 16.7 & 35.8 \\
\hline & -16 & 0.0 & 0.0 & 0.0 & 0.0 & & -16 & 0.0 & 0.0 & 0.0 & 0.0 \\
\hline & -20 & 0.0 & 0.0 & 0.0 & 0.0 & & -20 & 0.0 & 0.0 & 0.0 & 0.0 \\
\hline \multirow[t]{6}{*}{ 'Juanilo-92' } & 0 & 10.0 & 4.2 & 23.3 & 52.5 & 'ET-79-17' & 0 & 11.0 & 4.4 & 26.3 & 54.7 \\
\hline & -4 & 9.3 & 3.8 & 17.0 & 50.3 & & -4 & 9.6 & 4.3 & 21.7 & 45.3 \\
\hline & -8 & 9.1 & 3.7 & 16.3 & 41.2 & & -8 & 8.8 & 4.2 & 16.7 & 43.1 \\
\hline & -12 & 8.1 & 3.3 & 12.0 & 29.7 & & -12 & 7.4 & 3.3 & 12.7 & 37.7 \\
\hline & -16 & 0.0 & 0.0 & 0.0 & 0.0 & & -16 & 0.0 & 0.0 & 0.0 & 0.0 \\
\hline & -20 & 0.0 & 0.0 & 0.0 & 0.0 & & -20 & 0.0 & 0.0 & 0.0 & 0.0 \\
\hline \multirow[t]{6}{*}{ 'ET-83-20’ } & 0 & 6.9 & 4.7 & 15.7 & -5 & & & & & & \\
\hline & -4 & 6.3 & 4.3 & 14.3 & & & & & & & \\
\hline & -8 & 5.9 & 4.1 & 12.0 & & & & & & & \\
\hline & -12 & 5.3 & 3.8 & 10.3 & & & & & & & \\
\hline & -16 & 0.0 & 0.0 & 0.0 & & & & & & & \\
\hline & -20 & 0.0 & 0.0 & 0.0 & & & & & & & \\
\hline $\operatorname{LSD}(0.05)$ & & 0.7 & 0.4 & 3.7 & & & & & & & \\
\hline
\end{tabular}

(LN) Leaf number; (LA) Leaf area; (HH) Height at heading stage

also decreased. The maximum and the minimum leaf area were found at $0^{\circ} \mathrm{C}\left(22.9 \mathrm{~cm}^{2}\right)$ and $-12^{\circ} \mathrm{C}\left(13.2 \mathrm{~cm}^{2}\right)$, respectively (Tab. 2). The leaf area was $14 \%, 29 \%$ and $42 \%$ lower at $-4^{\circ} \mathrm{C},-8^{\circ} \mathrm{C}$, and $-12^{\circ} \mathrm{C}$ compared to the control condition (Tab. 2). Azizi et al. (2007) reported that leaf area of different wheat genotype was $28 \%$ lower at $-12^{\circ} \mathrm{C}$ compared to the control treatment. 'ET-82-15' showed the highest leaf area at the end of the recovery period and the minimum level was found for the 'ET-83-20' (Tab. 3). Azizi (2006) also found similar effect for wheat genotypes. He found the maximum and the minimum levels for 'Bezostaya' $(8.6 \mathrm{~cm})$ and 'Maron' $(3.2 \mathrm{~cm})$ genotype, respectively. The interaction between the genotype and the temperature on the leaf area was also significant $(\mathrm{P} \leq$ 0.01) (Tab. 1). The 'ET-82-15' showed the maximum leaf area at $0^{\circ} \mathrm{C}(26.7 \mathrm{~cm})$ and the minimum was obtained for 'ET-83-20' at $-12^{\circ} \mathrm{C}(10.3 \mathrm{~cm})$ (Tab. 5). When the temperature decreased from $0^{\circ} \mathrm{C}$ to $-12^{\circ} \mathrm{C}$ the reduction in the leaf area of 'ET-83-20' was 34\%. In this experiment the effect of freezing stress on the leaf area was more significant in relation to the number of leaves. The number of leaves decreased up to $23 \%$ by reducing the temperature from $0^{\circ} \mathrm{C}$ to $-12^{\circ} \mathrm{C}$, whereas the plant leaf area was more affected and decreased up to $42 \%$.

\section{Chlorophyll content (SPAD)}

Chlorophyll synthesis is one of the most temperature sensitive processes (Ilker et al., 1979). Chlorophyll content can be used as an indicator to determine the plants tolerance to coldness. Freezing temperature showed significant effect on leaf chlorophyll content $(\mathrm{P} \leq 0.01)$ of all genotypes (Tab. 1). As the temperature decreased, the plant chlorophyll content was also decreased. The maximum and the minimum chlorophyll content were found at $0^{\circ} \mathrm{C}$ (39.8) and $-12^{\circ} \mathrm{C}$ (33.6), respectively (Tab. 2). The chlorophyll content was $4.5 \%, 10.8 \%$ and $15.6 \%$ lower at $-4^{\circ} \mathrm{C}$, $-8^{\circ} \mathrm{C}$, and $-12^{\circ} \mathrm{C}$ compared to the control condition (Tab. 2). 'ET-83-20' and 'ET-82-8' showed the highest and the lowest chlorophyll content, respectively. It seems that low temperature not only affected the plant leaf area but also caused a clear reduction in the leaf chlorophyll content. Low temperature influenced the chlorophyll synthesize by changing the chloroplast structures and disorder the thylakoid membranes (McWilliams et al., 1979). Previously, 
Tab. 6. Correlation coefficients between plant parameters exposed to different freezing temperature and recovery in greenhouse

\begin{tabular}{|c|c|c|c|c|c|c|c|c|}
\hline Trait & 1 & 2 & 3 & 4 & 5 & 6 & 7 & 8 \\
\hline 1-EL leaf & 1 & & & & & & & \\
\hline 2-EL crown & $0.85^{*}$ & 1 & & & & & & \\
\hline 3-Height & $-0.84^{\prime \prime}$ & $-0.78^{* *}$ & 1 & & & & & \\
\hline 4-LN & $-0.89^{* *}$ & $-0.80^{* *}$ & $0.96^{\circ}$ & 1 & & & & \\
\hline 5-LA & $-0.87^{*}$ & $-0.81^{*}$ & $0.95^{*}$ & $0.93^{*}$ & 1 & & & \\
\hline 6-SPAD & $-0.88^{* \prime}$ & $-0.81^{*}$ & $0.95^{*}$ & $0.97^{*}$ & $0.92^{* \prime}$ & 1 & & \\
\hline 7-DW & $-0.88^{* \prime}$ & $-0.80^{* *}$ & $0.92^{*}$ & $0.92^{*}$ & $0.95^{\circ}$ & $0.91^{*}$ & 1 & \\
\hline 8-HH & $-0.70^{* *}$ & $-0.65^{\circ}$ & $0.88^{*}$ & $0.79^{* \prime}$ & $0.86^{\circ}$ & $0.76^{\circ}$ & $0.84^{*}$ & 1 \\
\hline
\end{tabular}

(EL\%) Electrolyte leakage percentage; (LN) Leaf number; (LA) Leaf area; (SPAD) Chlorophyll content; (DW) Total dry weight; (HH) Height at heading stage. ${ }^{* *}$ significant effects at $99 \%$

Azizi et al. (2006) working on wheat genotypes found that at $-12^{\circ} \mathrm{C}$ leaf chlorophyll content was $79 \%$ lower compared to the control condition.

\section{Dry weight}

The maximum and the minimum dry weight were found at $0^{\circ} \mathrm{C}(145 \mathrm{mg})$ and $-12^{\circ} \mathrm{C}(75.1 \mathrm{mg})$, respectively (Tab. 2). The plant dry weight was $17.6 \%, 32.6 \%$ and $48.2 \%$ lower at $-4^{\circ} \mathrm{C},-8^{\circ} \mathrm{C}$, and $-12^{\circ} \mathrm{C}$ compared to the control condition. This could be explained as a negative effect of the freezing stress on plant regrowth in the recovery period. Similarly, Chen et al. (1983) found the freezing temperatures of $-18^{\circ} \mathrm{C}$ and $-20^{\circ} \mathrm{C}$ decreased the wheat (Triticum aestivum L. cv 'Norstar' and 'Cappelle') plants regrowth $80 \%$ and $90 \%$, respectively. Azizi et al. (2006) also found that wheat dry weight was $81 \%$ lower at $-12^{\circ} \mathrm{C}$ compared to the control condition. In addition, the effect of different freezing temperatures on chickpea dry weight was significant (Nezami et al., 2007) and decreasing temperature from $-4^{\circ} \mathrm{C}$ to $-8^{\circ} \mathrm{C}$ caused $42 \%$ reduction in plants dry weight.

These differences $(\mathrm{P} \leq 0.01)$ were significant between the genotypes in their dry weight (Tab. 1). The 'ET-83-20' showed the minimum level of dry weight $(58 \mathrm{mg}$ ) while the maximum level was obtained for 'ET-79-17' (83 mg) (Tab. 3). In one experiment, Qian et al. (2001) observed that the shoot regrowth of buffalograss (Buchloe dactyloides (Nutt.) Engelm.] was extremely influenced by the freezing temperatures. They showed that for the sensitive genotypes, the decrease of temperature from $-8^{\circ} \mathrm{C}$ to $-12^{\circ} \mathrm{C}$ caused $60 \%$ reduction in plants dry weight.

\section{Plant height at heading stage}

The effect of different freezing temperatures on plant height at heading stage was significant (Tab. 1). The maximum and the minimum height were found at $0^{\circ} \mathrm{C}(46.9$ $\mathrm{cm})$ and $-12^{\circ} \mathrm{C}(28.5 \mathrm{~cm})$, respectively (Tab. 2). The plant height was $13.9 \%, 24.3 \%$ and $39.2 \%$ lower at $-4^{\circ} \mathrm{C},-8^{\circ} \mathrm{C}$, and $-12^{\circ} \mathrm{C}$ compared to the control condition. These differences were also significant $(\mathrm{P} \leq 0.01)$ even between genotypes (Tab. 1). Since, 'ET-82-15' had the maximum height and the shortest plants were produced from 'ET$83-20$ ' (Tab. 3). The interaction between the genotype and temperature on height was also significant $(\mathrm{P} \leq 0.01)$ (Tab. 1). The 'ET-82-15' had a maximum height at $0^{\circ} \mathrm{C}$ $(64 \mathrm{~cm})$ and the minimum level was obtained from the 'ET-83-20' at $-12^{\circ} \mathrm{C}$ (Tab. 5).

\section{Conclusions}

In this experiment, the leaves and crowns EL\% were extremely affected by the different freezing temperatures. Decreasing temperature down to $-4^{\circ} \mathrm{C}$ and $-8^{\circ} \mathrm{C}$ caused a significant increase in the EL\% of leaves and crowns, respectively. The EL\% of leaves and crowns at $-20^{\circ} \mathrm{C}$ was 3.2 and 1.2 times higher than control condition $\left(0^{\circ} \mathrm{C}\right)$. However, there were significant differences between the genotypes in their dry weight, height, leaf area, chlorophyll content and the height at the heading stage. The maximum leaf area and height at the heading stage was obtained for 'ET-82-15', while 'ET-79-18' produced the tallest seedlings with the most number of leaves and 'ET-79-17' had a maximum dry weight. The minimum dry weight, height and leaf area was obtained for 'ET-83-20' and did not produce any spike at all.

In this trial there was a positive correlation $\left(\mathrm{r}=0.85^{* *}\right)$ between the EL\% of leaves with the EL\% of crowns. In addition, a correlation between the EL\% with the other different measured parameters after the recovery period was negatively significant. The number of leaves showed highest negative correlation $\left(r=-0.89^{* *}\right)$ between the EL\% of leaves and the chlorophyll content. However, the leaf area had a good correlation $\left(\mathrm{r}=0.81^{* *}\right)$ with the EL\% of crowns. The leaves chlorophyll content and the plant height had highest correlation $\left(\mathrm{r}=0.97^{* *}\right),\left(\mathrm{r}=0.96^{*}\right)$ with the number of leaves. While, the dry weight and height at heading stage showed a good relation $\left(\mathrm{r}=0.88^{* *}\right)$ with the leaf area and the plant height, respectively (Tab. 6).

\section{References}

Ammar, K., M. Mergoum and S. Rajaram (2004). The history and evolution of triticale, p.1-11. In: M. Mergoum, Gomez-H. Macpherson, (Eds.). Triticale Improvement and Production. FAO Plant Production and Protection Paper. 
120

Anderson, J. A., C. M. Taliaferro and D. L. Martin (1993). Evaluating freeze tolerance of bermudagrass in a controlled environment. Hort Sci. 28:955.

Azizi, H., A. Nezami, M. Nassiri Mahallati and H. R. Khazaie (2007). Evaluation of cold tolerance in wheat (Triticum aestivum) cultivars under controlled conditions. Iranian J. Field Crops Resour. 5:109-121.

Barnett, R. D., R. L. Stanley, W. H. Chapman and R. L. Stith (1971). Triticale. New feed and forage crop for florida. Sunshine state Agric. Res. 12-14.

Brown, A. R. and A. Almodares (1976). Quantity and quality of triticale forage compared to other small grains. Agron. J. 68:264-266.

Chen, T. H., L. V. Gusta and D. B. Fowler (1983). Freezing injury and root development in winter cereals. Plant Physiol. 73:773-777.

Cloutier, Y. and D. Siminovitch (1982). Correlation between cold- and drought-induced frost hardiness in winter wheat and rye varieties. Plant Physiol. 69:256-258.

Dashti, H., B. Yazdi-Samadi, M. Ghannadha, S. Abd-Mishani and A. Sarafi (2001). Identification of chromosomes contributing to cold resistance in winter wheat by using substitution lines. Iranian, J. Agric. Sci. 32, 4. 825-833.

Eugenia, M., S. Nunes and G. Ray Smith (2003). Electrolyte leakage assay capable of quantifying freezing resistance in rose clover. Crop Sci. 43:1349-1357.

Fowler, D. B. and R. J. Carlers (1979). Growth, development, and cold tolerance of fall-acclimated cereal grains. Crop Sci. 19:915-922.

Ghamarnia, H. and J. W. Gowing (2005). Effect of Water Stress on Three Wheat Cultivars. ICID 21st European Regional Conference 2005-15-19 May. Frankfurt (Oder) and Slubice, Germany and Poland.

Gusta, L. V., D. B. Fowler and N. J. Tyler (1982). In: Factors influencing hardening and survival in winter wheat. P. H., Li, and Sakai, A. (Eds.). Plant Cold Hardiness and Freezing Stress. Mechanisms and Crop Implications. Academic Press, London.

Hommo, L. M. (1994). Hardening of some winter wheat (Triticum aestivum L.) rye (Secale cereale L.) and triticale (X Triticosecale wittmack) and winter barly (Hordeum vulgare L.) genotypes during autumn and the final winter survival in Finland. Plant Breed. 112:285-293.

Ilker, R., R. W. Breidenbach and J. M. Lyons (1979). Sequence of ultra structural changes in tomato cotyledons during short periods of chilling, p. 97-114. In: Lyons, J. M., D. Graham and J. K. Raison (Eds.). Low Temperature Stress in Crop Plants. New York Academic Press.

Lindow, S. E., D. C. Arny and C. D. Upper (1982). Bacterial ice nucleation: A factor in frost injury to plants. Plant Physiol. 70:1084-1089.

Lyons, J. M. and J. K. Raison (1990). Oxidative activity of mitochondria isolated from plant tissues sensitive and resistant to chilling injury. Plant Physiol. 45:386-389.

McWilliams, W., W. Manokaran and T. Kipnis (1979). In: Adaptation to chilling stress in sorghum. J. M. Lyons, D. Graham, and J. K. Raison (Eds.). Low Temperature Stress in Crop Plants: The Role of Membrane. New York: Academic Press.

Mirzai-Asl, A., B. Yazdi-Samadi, A. Zali and Y. SadeghianMotahhar (2002). Measuring cold resistance in wheat by laboratory tests. Iranian J. Sci and Technol. Agric. and Natur. Resour. 6:177-186.

Moshiri, F., A. Bagheri and A. Safarnejad (2006). The effect of cold acclimation on freezing tolerance of three chickpea (Cicer arietinum L.) cultivars. Iranian J. Agri. Sci. Natur. Reasour.12:153-160.

Murray, S., M. U. Webb and P. Steponkus (1994). A comparison of freezing injury in oat and rye: Two cereals at the extremes of freezing tolerance. Plant Physiol. 104:467-478.

Murray, G. A., D. Eser, L. V. Gusta and G. Eteve. (1994). Winter hardiness in pea, lentil, faba bean and chickpea p. 831-843. In: R.J. Summerfield (Eds.), World Crops: Cool Season Food Legumes. Kluwer Academic Publishers, Dordrecht The Netherlands.

Nezami, A. (2002). Evaluation of chilling stress in chickpea (Cicer arietinum L.). PhD Thesis, Ferdowsi University of Mashhad. (In Farsi).

Nezami, A., A. Bagheri, H. Rahimian, M. Kafi and M. Nasiri Mahalati (2007). Evaluation of freezing tolerance of chickpea (Cicer arietinum L.) genotypes under controlled conditions. Iranian J. Sci and Technol. Agric. and Natur. Resour. 10:257-269.

Nezami, A., A. Borzooei, M. Jahani, M. Azizi and A. Sharif (2007). Electrolyte leakage as an indicator of freezing injury in colza (Brassica napus L.). Iranian J. Field Crops Resour. 5:167-177.

Pulli, S. (1994). Conductivity testing for screening the winter hardiness of cereals, grasses and legumes. Nordisk Jordisk Jordbruksforskning 76:58-59.

Qian, Y. L., S. Z. Ball, A. J. Tan, S. J. Koski and S. J. Wilhelm (2001). Freezing tolerance of six genotypes of buffalograss. Crop Sci. 41:1174-1178.

Ristic, Z. and E. N. Ashworth (1997). Mechanisms of freezing resistance of wood tissues, p.123-137: In: Recent advancements. A. S. Basra, R. K. Basra (Eds.). Mechanisms of Environmental Stress Resistance in Plants. Amesterdam B. V. 